\title{
Person Marital Status Code
}

National Cancer Institute

\section{Source}

National Cancer Institute. Person Marital Status Code. NCI Thesaurus. Code C93988.

A coded value specifying the domestic partnership status of a person. 